\title{
Land-use impact on selected forms of arsenic and phosphorus in soils of different functions
}

\author{
Andrzej Plak*, Piotr Bartmiński, and Ryszard Dębicki \\ Department of Soil Science and Protection, Maria Curie-Skłodowska University in Lublin, Kraśnicka 2cd, 20-718 Lublin, Poland
}

Received December 7, 2016; accepted August 7, 2017

\begin{abstract}
The aim of the study was to assess the impact of technosols and geomechanically unchanged soils of the Lublin agglomeration on the concentrations of arsenic and phosphorus, and on selected forms of these elements. Arsenic and phosphorus concentrations were determined in the urban soils of Lublin (Poland), and the relationship between their degree of contamination and different types of land use was estimated. The samples collected were subjected to sequential analysis, using ammonium sulphate, acid ammonium phosphate, oxalate buffer (also with ascorbic acid) and aqua regia for arsenic, and ammonium chloride, sodium hydroxide, hydrochloric acid and aqua regia for phosphorus. The influence of the land use forms was observed in the study. The greatest amount of arsenic (19.62 $\mathrm{mg} \mathrm{kg}^{-1}$ ) was found in the industrial soils of Lublin, while the greatest amount of phosphorus (580.4 $\mathrm{mg} \mathrm{kg}^{-1}$ ) was observed in non-anthropogenic soils (mainly due to the natural accumulation processes of this element). Fractions of arsenic and phosphorus obtained during analysis showed strong differentiation. Amorphic and crystalline fractions of arsenic, bound with iron oxides, proved to have the highest share in the total arsenic pool. The same situation was noted for phosphorus.

Keywords: soil pollution, sequential speciation, environmental quality
\end{abstract}

\section{INTRODUCTION}

The release of toxic arsenic compounds from soils to other environmental components, including to ground water, and its uncontrolled mobilisation into soil constitute major problems, posing danger to human health. Soil-held arsenic is an important source of contamination of plants, food, surface and groundwater, as well as drinking water. Moreover, arsenic compounds have carcinogenic and mutagenic effects on human and animal organisms, thus

*Corresponding author e-mail: aplak@poczta.umcs.lublin.pl bringing serious risks to their health. The toxicity of this element is mainly due to arsenates (V) having similarity to phosphates, thus inducing abnormal biochemical changes. However, the bioavailability and toxicity of arsenic, as well as its behaviour in the environment, depend on the chemical form of the element (Frankenberger, 2002; Nriagu, 1994).

Cities are areas with high anthropogenic activity, where local emission sources of arsenic are often numerous (Luo et al., 2008; Wong et al., 2006). As a result of the development of various sectors of industry, especially in urban areas, where large quantities of dust, waste and sewage are produced, an increase in the concentration of this element is observed. Arsenic compounds can be released in several ways, for instance through emissions from the chemical industry, coal burning, biomass and garbage combustion, municipal waste and emissions or dust-falls (Frankenberger, 2002; Jiang et al., 2015).

For centuries, the presence of arsenic in soil has been connected with human activity. Arsenic levels in the soil solution, synergism and antagonism of arsenic with other elements, and also the quantitative ratio of these elements constitute factors regulating the adsorption capacity of plants or the potential underground water contamination (Plak, 2007). The negative impact of arsenic toxins on the chemical composition of plants and soil microorganisms can be minimised by soil $\mathrm{pH}$ regulation or through the use of chemical compounds promoting the immobilisation or mobilisation of this element in soil. Arsenic stabilisation is, therefore, a far more rational measure than the contaminant removal from soil. 
Phosphorus, found in different soil forms, can effectively compete against arsenate ions $\mathrm{AsO}_{4}{ }^{3-}$ in the adsorption processes in different soil forms, including in particular in agricultural soils which are frequently fertilised with phosphorus compounds. Indeed, this element is one of the diagnostic indicators employed in paleopedology research, considering that the long-term human impact on soil is widely considered to often lead to elevated phosphorus content (Lauer et al., 2013; Nielsen and Kristiansen, 2014). In the past, the main anthropogenic sources of this element in soil were human and animal faeces, food scraps or plant waste (Rodrigues and da Costa, 2016). At present, the main reasons of an elevated concentration of phosphorus are intensive farming, chemical industry emissions, as well as the combustion of coal and biomass (Chen et al., 2008; Zhao and Xia, 2012).

An extensive body of literature exists on the phenomenon of the competitive adsorption of phosphate and arsenate ions which are sorbed on various soil components. Such studies show that the distribution of arsenic and phosphorus in soil is characterised by high volatility and a high degree of interrelation (Bolan et al., 2013; Hartley et al., 2010; Lu et al., 2011). This can be explained by their chemical similarity. These two elements belong to the same chemical group, and show similarity in both electron configurations and the affinity to selected elements (Ascar et al., 2008; Nriagu, 1994). Moreover, some bacteria are able to use arsenic as a building element in the absence of phosphorus in their living environment (Wolfe-Simon et al., 2011). The presence of these two elements in soil depends on the chemical form in which they occur, as well as on the composition and physicochemical properties of soil.

Speciation analysis provides an efficient tool for analysing the lifetime of both elements. Such analysis consists in removing from soil the arsenic and phosphorus fractions which are associated with various components of soil. The method of sequential extraction consists of a consecutive usage of reagents for the extraction of particular element forms, on the basis of their solution in different kinds of solvents. While this may be an effective method for assessing the share of element compounds with different mobility, some disadvantages related to employing this method have also been reported, including the lack of reagent selectiveness, the lack of quality control or dependence of the obtained effects on the procedure selected (Krysiak and Karczewska, 2007). The total content of soil-held arsenic and phosphorus does not fully reflect the concentration of these element forms. However, it is a crucial indicator for assessing the quality of the environment. Sequential extraction, used for both arsenic and phosphorus, is based on the analytic scheme proposed by Chang Jackson (1957), which takes into account the anionic character of arsenic and phosphorus compounds present in soil (Pardo et al., 2003; Wenzel et al., 2001).
The aim of the study was to evaluate the impact of technosols and geomechanically unchanged soils of the Lublin agglomeration on the concentrations of arsenic and phosphorus, and on selected forms of these elements. While studies on the competitiveness of phosphorus and arsenic ions in soil have been carried out by many researchers, this paper focuses primarily on the behaviour of both elements in the competitiveness of their sequential forms, while simultaneously taking into account the functional division of soils.

\section{MATERIALS AND METHODS}

Lublin ( $\mathrm{N} 51^{\circ} 14^{\circ}$; E $\left.22^{\circ} 33^{\circ}\right)$ is a city located in the eastern part of Poland, on the Lublin Upland, on the Bystrzyca River. The Lublin agglomeration covers the administrative area of the city and the surrounding communities adjacent to the city borders. The outskirts of the agglomeration include forested lands, croplands and small villages, whose inhabitants work in Lublin. Herein, historical conditions have played a specific role in the formation of the agglomeration's anthropogenic soils. Namely, natural soils were transformed as a result of the infrastructure development, as well as through the industrial and communication impact (Kociuba, 2011). The soils examined in this study occur in different parts of the Lublin agglomeration, and are diverse in terms of functions and taxonomy. Two test groups of soils were isolated for this purpose.

The first group comprises technosols which represent the most characteristic type of land use in the city. The profiles examined, according to the WRB (IUSS Working Group WRB, 2014) classification, include the following. Profile No. 1, Haplic Regosol (Calcaric, Endoeutric, Siltic), is where a shopping centre is under construction. Profile No. 2, Spolic Technosol (Calcaric), is an industrial zone soil found in the proximity of a coal-fired power station. Profile No. 3, Urbic Technosol (Calcaric), was sampled from the academic campus square, which also has a recreational function. Profile No. 4, Spolic Technosol (Calcaric), was taken from the industrial part of the city, near some railway tracks, in the immediate vicinity of one of the most congested points of the city. Profile No. 5, Urbic Technosol (Calcaric), was taken from a piece of city greenery adjacent to an area with compact multi-family buildings. All soils from this group are characterized by a significant share of artefacts such as industrial dusts, slag, building rubble and asphalt in the profiles.

The second group consists of geomechanically unchanged soils (not mixed or deposited). In terms of function, these are agricultural and forest soils. Soil profile No. 6, Haplic Regosol (Epieutric), was obtained from outside the city, in a forest within the agglomeration. It was classified as Haplic Regosol (Epieutric). Profile No. 8, Haplic Luvisol (Siltic), was obtained from the forest greenbelt bordering the city and the suburban zone, with the land 
use being similar to that of a city park. Profiles Nos 7 and 9, both natural Haplic Luvisols (Siltic), are from croplands within the agglomeration suburban zone. These soil profiles are similar to natural soils, taking into account their use.

All soil samples were collected from particular horizons, distinguished on the basis of profile characteristics, according to the World Reference Base. Each soil sample was air-dried at room temperature until constant mass was obtained, and were then crushed and sieved to separate the $<2 \mathrm{~mm}$ fractions from any gravel or larger detritus.

The following soil physiochemical properties were determined: texture using the Casagrande areometric method, as modified by Prószyński (Ryżak et al., 2009), pH potentiometrically in $1 \mathrm{~mol} \mathrm{l}^{-1} \mathrm{KCl}$ (ISO 10390:1994), total organic carbon (TOC) - via the wet combustion method (Nelson and Sommers 1996), and the $\mathrm{CaCO}_{3}$ content using Scheibler's volumetric method (Ostrowska et al., 1991). The sum of exchangeable bases (TEB) (Ca, Mg, K, and Na) was extracted from soil with $1 \mathrm{M}$ ammonium chloride and determined by means of the AAS flame technique, while hydrolytic acidity $(\mathrm{Hh})$ was estimated using the Kappen method. The cation exchange capacity (CEC) of soils was calculated as a sum of hydrolytic acidity $(\mathrm{Hh})$ and total exchangeable bases (Ca, Mg, K, Na) - (TEB).

The collected samples were then subjected to sequential analysis (Table 1). Analysis of arsenic was conducted according to the methodology of Wenzel et al., (2001), and analysis of phosphorus according to the Chang-Jackson method, modified by Hieltjes-Lijklema (1980). The residue was mineralised with aqua regia (ISO 11466:1995). Indication of arsenic at all stages of sequential extraction was carried out by way of the hydride generation method, on an AAS Perkin Elmer 3300 spectrometer with FIAS 400 attachment. Indication of phosphorus was ascertained using the ascorbic acid method (Kuo, 1996), on a spectrophotometer Lambda 12 from Perkin Elmer. The following

Table 1. Scheme of sequential analysis of arsenic and phosphorus extraction in the examined soils

\begin{tabular}{|c|c|c|c|c|c|}
\hline $\begin{array}{l}\text { Arsenic } \\
\text { fraction }\end{array}$ & Description & $\begin{array}{l}\text { Arsenic extraction } \\
\text { conditions }\end{array}$ & $\begin{array}{l}\text { Phosphorus } \\
\text { fractions }\end{array}$ & Description & $\begin{array}{l}\text { Phosphorus extraction } \\
\text { conditions }\end{array}$ \\
\hline NSA & $\begin{array}{l}\text { arsenic forms not } \\
\text { specifically fixed } \\
\text { with soil } \\
\text { components }\end{array}$ & $\begin{array}{l}0.05 \mathrm{~mol} \mathrm{dm}^{-3} \\
\left(\mathrm{NH}_{4}\right)_{2} \mathrm{SO}_{4} \text {, shaking } \\
\text { for } 4 \mathrm{~h} \text {, centrifugation, } \\
\text { decantation }\end{array}$ & SP & $\begin{array}{l}\text { phosphorus forms not } \\
\text { specifically fixed with } \\
\text { soil components }\end{array}$ & $\begin{array}{l}1 \mathrm{~mol} \mathrm{dm}^{-3} \mathrm{NH}_{4} \mathrm{Cl} \text {, shaking for } \\
2 \mathrm{~h} \text { (two-fold), centrifugation, } \\
\text { decantation }\end{array}$ \\
\hline SA & $\begin{array}{l}\text { arsenic forms } \\
\text { specifically fixed } \\
\text { with soil } \\
\text { components }\end{array}$ & $\begin{array}{l}0.05 \mathrm{~mol} \mathrm{dm}^{-3} \\
\left(\mathrm{NH}_{4}\right) \mathrm{H}_{2} \mathrm{PO}_{4} \text { shaking } \\
\text { for } 16 \mathrm{~h} \text {, } \\
\text { centrifugation, } \\
\text { decantation }\end{array}$ & NAP & $\begin{array}{l}\text { phosphorus forms } \\
\text { fixed with oxides and } \\
\text { hydroxides of iron, } \\
\text { aluminium and } \\
\text { manganese 'non } \\
\text { apatite' phosphorus }\end{array}$ & $\begin{array}{l}0.1 \mathrm{~mol} \mathrm{dm}-3 \mathrm{NaOH} \text { shaking } \\
\text { for } 17 \mathrm{~h} \text {, centrifugation, } \\
\text { decantation }\end{array}$ \\
\hline AA & $\begin{array}{l}\text { arsenic forms fixed } \\
\text { with amorphic, } \\
\text { hydrated oxides }\end{array}$ & $\begin{array}{l}0.2 \mathrm{~mol} \mathrm{dm} \mathrm{d}^{-3} \text { oxalate } \\
\text { buffer, } \mathrm{pH} 3.25 \text {; } \\
\text { shaking } 4 \mathrm{~h} \text { in the } \\
\text { dark, centrifugation, } \\
\text { decantation, washing } \\
\text { with oxalate buffer by } \\
\text { shaking in the dark for } \\
10 \text { min }\end{array}$ & $\mathrm{AP}$ & $\begin{array}{l}\text { phosphorus forms } \\
\text { fixed with calcium, } \\
\text { 'apatite' phosphorus }\end{array}$ & $\begin{array}{l}0.5 \mathrm{~mol} \mathrm{dm} \mathrm{m}^{-3} \mathrm{HCl} \text {, shaking for } \\
24 \mathrm{~h} \text {, centrifugation, } \\
\text { decantation }\end{array}$ \\
\hline $\mathrm{CA}$ & $\begin{array}{l}\text { arsenic forms fixed } \\
\text { with crystalline } \\
\text { oxides }\end{array}$ & $\begin{array}{l}0.2 \mathrm{~mol} \mathrm{dm} \mathrm{d}^{-3} \text { oxalate } \\
\text { buffer }+0.1 \mathrm{~mol} \mathrm{dm} \\
\text { Ascorbic acid, } \mathrm{pH}= \\
3.25 \text {; at. } 96^{\circ} \mathrm{C}, \\
\text { centrifugation, } \\
\text { decantation, washing } \\
\text { with oxalate buffer by } \\
\text { shaking in the dark for } \\
10 \text { min }\end{array}$ & $\mathrm{OP}$ & $\begin{array}{l}\text { phosphorus forms } \\
\text { fixed with organic } \\
\text { matter }\end{array}$ & $\mathrm{OP}=\mathrm{TP}-(\mathrm{SP}+\mathrm{NAP}+\mathrm{AP})$ \\
\hline RA & arsenic residue & $\begin{array}{l}\text { aqua regia }(16 \mathrm{~h} \text { at } \\
\text { room temp. }+2 \mathrm{~h} \text { at } \\
130^{\circ} \mathrm{C} \text {, under reflux } \\
\text { condenser) }\end{array}$ & $\mathrm{TP}$ & $\begin{array}{l}\text { total phosphorus } \\
\text { content }\end{array}$ & $\begin{array}{l}\text { aqua regia }(16 \mathrm{~h} \text { at room temp. } \\
+2 \mathrm{~h} \text { at } 130^{\circ} \mathrm{C}\end{array}$ \\
\hline
\end{tabular}


fractions were distinguished: SP phosphorus forms not specifically fixed with soil components, 'non apatite' phosphorus (NAP) forms fixed with oxides and hydroxides of iron, aluminium and manganese, 'apatite' phosphorus (AP) forms fixed with calcium, phosphorus forms fixed with organic matter (OP), total phosphorus (TP) content, NSA arsenic forms not specifically fixed with soil components, arsenic forms specifically fixed with soil components (SA), arsenic forms fixed with amorphic, hydrated oxides (AA), arsenic forms fixed with crystalline oxides (RA), and arsenic residue (TA).

Analysis of the arsenic content was verified with the Standard Reference Material ${ }^{\circledR} 2709$ San Joaquin Soil. The precision of the test of reference material was equal to $2.1 \%$ for As and to $6.4 \%$ for P.

The analytic data was subjected to statistical analysis, using Statistica software (ver. 10). Correlation coefficients were calculated for all soil parameters, significance was checked at $p<0.05$. Additionally, correspondences were tested within two groups - anthropogenic and non-anthropogenic profiles. Analysis of the main factors principal component analysis (PCA), accounting for all the analysed variables was conducted in order to determine the differences between two profile groups.

\section{RESULTS AND DISCUSSION}

The basic properties of the analysed soils are given in Table 2. As shown, the grain-size distribution of the investigated soils is slightly varied. In the group of technosols, some differences in the share of particular fractions may be observed, with the soils classified as being sandy loam, loam and also loamy sand. The second group of soils showed the textures of silt loams and clay loams. The reaction of the technosols analysed was alkaline (7.1 to 7.9), and the cation exchange capacity varied from 23.3 to $67.0 \mathrm{cmol}$ $\mathrm{kg}^{-1}$, with base saturation at the level over $97 \%$. In the case of the non-anthropogenic soils, $\mathrm{pH}$ ranged from 3.41 to 7.85 and CEC - from 5.0 to $74.5 \mathrm{cmol} \mathrm{kg}^{-1}$ whereas the base saturation was varied. The organic carbon content in the anthropogenic soils fluctuated from 3.0 to $59.0 \mathrm{~g} \mathrm{~kg}^{-1}$, with the highest values being observed in the surface horizons. The profile distribution of carbon was typical for technosols, showing a significant vertical dynamics. In the soils of the second group, the highest content of organic carbon was noted in the surface horizons - up to $325.5 \mathrm{~g} \mathrm{~kg}^{-1}$, with the share decreasing with depth, to $0.2 \mathrm{~g} \mathrm{~kg}^{-1}$.

Both the soils of anthropogenic and non-anthropogenic origins showed diversity in terms of arsenic and phosphorus content.

The technosols group was characterised by the content of arsenic ranging from 0.36 to $19.62 \mathrm{mg} \mathrm{kg}^{-1}$ (Table 3). These did not exceed the limit specified in the Regulation of the Minister of Environment on soil quality standards and ground quality standards. However, the anthropogenic factors, including location in the industrial zone or residential area, street vicinity and automobile derived pollution, as well as recreational functions of the examined locations, may have impact on the soil arsenic content.

Soil profile No. 2 is located in the industrial zone, and showed the highest arsenic content in relation to the rest of tested soils. However, generally speaking, the average total content in technosols was $16.02 \mathrm{mg} \mathrm{kg}^{-1}$. Still, soils in the communication zone (Profile No. 4) averaged a total content of arsenic at a level of $5.34 \mathrm{mg} \mathrm{kg}^{-1}$. In almost all of the investigated profiles, the arsenic accumulation was found primarily in the surface levels. The lowest content of total arsenic and its forms concerned Profile No. 5, which may be due to the location of the research area in a new residential estate, where there is a mixture of deeper layers with the surface or where brought-in soil (poorer in pollutants) was used as top-dressing.

The phosphorus content in technosols ranged from 47.0 to $178.9 \mathrm{mg} \mathrm{kg}^{-1}$, with a characteristic peak in accumulation levels in all profiles. Therefore, the vertical (profile) distribution of the total content of both elements ( $\mathrm{P}$ and As) displayed great similarity (Table 4). The highest values of $\mathrm{P}$ were observed in Profile 2, due to its location in an industrial area where soils are subjected to specific pressure connected with metallurgic processes and deposition of power plant substrate.

It was noted that the organic matter content and grain size distribution had the greatest impact on the accumulation of phosphorus and arsenic. This effect was also confirmed through other studies (Frankenberger, 2002; Torbert et al., 2002; Wenzel et al., 2001). The soils examined showed affinity for even the tiniest fractions of both elements, as indicated by Garcia-Sanchez et al. (2002) by immobilising arsenic though the addition of clay minerals. The amounts of phosphate adsorbed in soils proved to be higher than arsenates. Moreover, phosphates were found to be sorbed by soil colloids and hydrated oxides of aluminium and iron, while arsenates were sorbed predominantly by iron oxides and hydroxides (Goldberg, 2002; and Violante and Pigna, 2002).

The soils in the second group were characterised by the arsenic content ranging from 2.69 to $12.24 \mathrm{mg} \mathrm{kg}^{-1}$. This did not exceed the limit specified in the Regulation of the Minister of Environment on soil quality standards and ground quality standards. Accumulation of this element was determined primarily in the Bt horizon. The phosphorus content in the examined soils ranged from 218.0 to $580.4 \mathrm{mg} \mathrm{kg}^{-1}$, with a characteristic peak in the horizons levels of accumulation and enrichment. Both elements under consideration showed affinity to the smallest fraction of the investigated soils, and their high concentrations were observed in Bt horizons. Additionally, soils of the second group were developed from the same parent material (Plak, 2007). Therefore, profile distribution of the total content of both elements showed great similarity. 
Table 2. Characteristics of studied soil profiles of Lublin agglomeration

\begin{tabular}{|c|c|c|c|c|c|c|c|c|c|}
\hline \multirow{2}{*}{$\begin{array}{l}\text { Profile } \\
\text { No. }\end{array}$} & \multirow{2}{*}{$\mathrm{RSG}^{\mathrm{a}}$} & \multirow{2}{*}{ Texture } & \multirow{2}{*}{ Value } & \multirow{2}{*}{$\begin{array}{l}\text { C org. }{ }^{b} \\
\left(\mathrm{~g} \mathrm{~kg}^{-1}\right)\end{array}$} & \multirow{2}{*}{$\mathrm{pH}^{\mathrm{c}}$} & \multirow{2}{*}{$\begin{array}{l}\mathrm{CaCO}_{3}{ }^{\mathrm{d}} \\
\left(\mathrm{g} \mathrm{kg}^{-1}\right)\end{array}$} & $\mathrm{Hh}^{\mathrm{e}}$ & $\mathrm{TEB}^{\mathrm{f}}$ & $\mathrm{CEC}^{\mathrm{g}}$ \\
\hline & & & & & & & \multicolumn{3}{|c|}{$\left(\mathrm{cmol} \mathrm{kg}^{-1}\right)$} \\
\hline \multirow{3}{*}{1} & \multirow{3}{*}{$\begin{array}{l}\text { Haplic Regosol } \\
\text { (Calcaric, } \\
\text { Endoeutric, } \\
\text { Siltic) }\end{array}$} & \multirow{3}{*}{$\mathrm{SiL} / \mathrm{L} / \mathrm{SL}$} & Range & $3.0-52.0$ & $7.1-7.5$ & $8.0-195.0$ & $2.4-9.8$ & $\begin{array}{c}229.0- \\
660.6\end{array}$ & $\begin{array}{l}233.2- \\
670.4\end{array}$ \\
\hline & & & Avg. & 16.8 & 7.3 & 75.8 & 4.7 & 432.8 & 437.5 \\
\hline & & & $\mathrm{SD}$ & 23.6 & 0.2 & 81.9 & 3.5 & 176.7 & 179.3 \\
\hline \multirow{3}{*}{2} & \multirow{3}{*}{$\begin{array}{l}\text { Spolic } \\
\text { Technosol } \\
\text { (Calcaric) }\end{array}$} & \multirow{3}{*}{$\mathrm{SL} / \mathrm{L}$} & Range & $10.0-39.0$ & $7.2-7.4$ & $\begin{array}{c}154.0- \\
181.0\end{array}$ & $3.6-5.2$ & $\begin{array}{l}592.1- \\
637.7\end{array}$ & $\begin{array}{l}595.7- \\
642.9\end{array}$ \\
\hline & & & Avg. & 22.7 & 7.3 & 171.0 & 4.6 & 607.9 & 612.5 \\
\hline & & & $\mathrm{SD}$ & 14.8 & 0.1 & 14.8 & 0.9 & 25.8 & 26.4 \\
\hline \multirow{3}{*}{3} & \multirow{3}{*}{$\begin{array}{l}\text { Urbic } \\
\text { Technosol } \\
\text { (Calcaric) }\end{array}$} & \multirow{3}{*}{ SL } & Range & $10.8-27.0$ & $7.6-7.8$ & $36.6-120.6$ & $5.6-7.2$ & $\begin{array}{c}380.2- \\
436.4\end{array}$ & $\begin{array}{c}385.8- \\
442.8\end{array}$ \\
\hline & & & Avg. & 20.7 & 7.7 & 56.1 & 6.1 & 409.4 & 415.5 \\
\hline & & & $\mathrm{SD}$ & 6.3 & 0.1 & 32.1 & 0.7 & 20.3 & 20.7 \\
\hline \multirow{3}{*}{4} & \multirow{3}{*}{$\begin{array}{l}\text { Spolic } \\
\text { Technosol } \\
\text { (Calcaric) }\end{array}$} & \multirow{3}{*}{$\mathrm{LS} / \mathrm{SL}$} & Range & $8.0-59.0$ & 7.6-7.9 & $44.0-59.0$ & $4.6-10.8$ & $\begin{array}{c}412.0- \\
543.7\end{array}$ & $\begin{array}{l}417.9- \\
548.3\end{array}$ \\
\hline & & & Avg. & 27.2 & 7.8 & 50.8 & 7.7 & 478.4 & 486.1 \\
\hline & & & SD & 21.1 & 0.2 & 5.4 & 3.0 & 49.1 & 48.9 \\
\hline \multirow{3}{*}{5} & \multirow{3}{*}{$\begin{array}{l}\text { Urbic } \\
\text { Technosol } \\
\text { (Calcaric) }\end{array}$} & \multirow{3}{*}{ SL } & Range & $8.0-26.0$ & $7.1-7.6$ & $0.0-45.0$ & $2.8-7.2$ & $\begin{array}{l}322.2- \\
444.6\end{array}$ & $\begin{array}{c}327.8- \\
447.8\end{array}$ \\
\hline & & & Avg. & 15.0 & 7.4 & 28.3 & 4.7 & 362.3 & 367.0 \\
\hline & & & $\mathrm{SD}$ & 8.7 & 0.2 & 14.5 & 2.1 & 57.3 & 55.9 \\
\hline \multirow{3}{*}{6} & \multirow{3}{*}{$\begin{array}{l}\text { Haplic Regosol } \\
\text { (Epieutric) }\end{array}$} & \multirow{3}{*}{$\mathrm{SiL}$} & Range & $1.0-325.5$ & $3.41-7.85$ & $0.0-100.4$ & $0.4-46.8$ & $0.3-62.4$ & $6.1-74.5$ \\
\hline & & & Avg. & 105.6 & 4.5 & 14.3 & 15.9 & 14.9 & 30.8 \\
\hline & & & SD & 259.8 & 1.6 & 37.9 & 18.9 & 23.0 & 28.2 \\
\hline \multirow{3}{*}{7} & \multirow{3}{*}{$\begin{array}{l}\text { Haplic Luvisol } \\
\text { (Siltic) }\end{array}$} & \multirow{3}{*}{$\mathrm{SiCL}$} & Range & $0.2-7.8$ & $4.4-7.6$ & $0.0-80.0$ & $0.37-6.1$ & $3.4-50.6$ & $8.2-51.0$ \\
\hline & & & Avg. & 1.8 & 5.0 & 13.3 & 3.3 & 12.6 & 15.9 \\
\hline & & & SD & 3.0 & 1.3 & 32.5 & 2.4 & 18.7 & 17.3 \\
\hline \multirow{3}{*}{8} & & & Range & $0.5-245.5$ & $3.7-4.9$ & - & $2.2-19.6$ & $0.6-17.5$ & $5.0-37.2$ \\
\hline & $\begin{array}{l}\text { Haplic Luvisol } \\
\text { (Siltic) }\end{array}$ & $\mathrm{SiL}$ & Avg. & 37.3 & 4.0 & - & 6.1 & 6.1 & 12.1 \\
\hline & & & SD & 91.8 & 0.4 & - & 6.1 & 5.8 & 11.3 \\
\hline & & & Range & $0.6-7.7$ & $3.9-7.3$ & $0.0-43.2$ & $0.2-5.1$ & $4.9-49.4$ & $6.9-49.7$ \\
\hline 9 & $\begin{array}{l}\text { Haplic Luvisol } \\
\text { (Siltic) }\end{array}$ & $\mathrm{SiL}$ & Avg. & 2.3 & 4.6 & 9.0 & 2.6 & 14.8 & 17.4 \\
\hline & & & SD & 3.1 & 1.5 & 19.3 & 1.9 & 19.4 & 18.2 \\
\hline
\end{tabular}

${ }^{\mathrm{a}}$ Reference Soil Group, according to IUSS Working Group (2014), ${ }^{\mathrm{b}}$ organic carbon, ${ }^{\mathrm{c}}$ soil reaction, ${ }^{\mathrm{d}}$ calcium carbonate content, ${ }^{\mathrm{e}}$ hydrolytic acidity (exchangeable hydrogen), ${ }^{\mathrm{f}}$ total exchangeable bases, ${ }^{\mathrm{g}}$ cation exchange capacity. 
Table 3. Concentration of particular forms of arsenic in the examined soils ( $\left.\mathrm{mg} \mathrm{kg}^{-1}\right)$

\begin{tabular}{|c|c|c|c|c|c|c|c|}
\hline $\begin{array}{c}\text { Profile } \\
\text { No. }\end{array}$ & Horizon & NSA & SA & AA & $\mathrm{CA}$ & RA & TA \\
\hline \multirow{4}{*}{1} & $\mathrm{Ak}$ & 0.17 & 0.78 & 2.75 & 1.23 & 1.19 & 5.08 \\
\hline & $2 \mathrm{Ck} 1$ & 0.12 & 0.92 & 2.71 & 1.16 & 1.57 & 6.65 \\
\hline & $3 \mathrm{Ck} 2$ & 0.05 & 0.29 & 1.32 & 1.34 & 1.38 & 4.83 \\
\hline & $3 \mathrm{Ck} 3$ & 0.04 & 0.25 & 1.13 & 1.74 & 0.96 & 3.57 \\
\hline \multirow{3}{*}{2} & Auk & 0.78 & 1.17 & 5.98 & 4.55 & 5.12 & 19.62 \\
\hline & Cuk1 & 0.06 & 0.81 & 2.43 & 2.86 & 2.96 & 15.80 \\
\hline & 2Cuk2 & 0.06 & 0.71 & 1.89 & 5.34 & 1.80 & 12.65 \\
\hline \multirow{3}{*}{3} & Ak1 & 0.19 & 0.26 & 0.93 & 0.34 & 1.04 & 3.28 \\
\hline & Cuk2 & 0.13 & 0.13 & 0.55 & 0.15 & 0.69 & 2.09 \\
\hline & $\mathrm{Ck} 3$ & 0.05 & 0.11 & 0.47 & 0.17 & 0.54 & 1.88 \\
\hline \multirow{4}{*}{4} & $\mathrm{Ak}$ & 0.23 & 0.45 & 2.37 & 1.57 & 1.61 & 6.15 \\
\hline & 2Cuk1 & 0.19 & 0.25 & 1.89 & 1.91 & 1.64 & 4.91 \\
\hline & 2Cuk2 & 0.14 & 0.55 & 1.64 & 1.94 & 1.60 & 5.33 \\
\hline & $2 \mathrm{Ck} 3$ & 0.09 & 0.85 & 1.68 & 0.61 & 1.85 & 5.07 \\
\hline \multirow{4}{*}{5} & Ak1 & 0.32 & 0.13 & 0.41 & 0.05 & 0.27 & 0.76 \\
\hline & $\mathrm{Au} 2$ & 0.03 & 0.06 & 0.16 & 0.01 & 0.16 & 0.48 \\
\hline & Cuk1 & 0.03 & 0.06 & 0.10 & 0.01 & 0.25 & 0.51 \\
\hline & Cuk2 & 0.07 & 0.07 & 0.11 & 0.01 & 0.28 & 0.36 \\
\hline \multirow{4}{*}{6} & A & 0.02 & 0.42 & 0.75 & 1.75 & 2.14 & 5.21 \\
\hline & AEet & 0.01 & 0.15 & 1.61 & 0.94 & 2.24 & 4.26 \\
\hline & $\mathrm{Bt}$ & 0.01 & 0.32 & 2.32 & 2.95 & 3.44 & 7.10 \\
\hline & Cca & 0.05 & 0.56 & 1.17 & 1.95 & 1.84 & 6.51 \\
\hline \multirow{3}{*}{7} & $\mathrm{ApBt}$ & 0.02 & 0.11 & 1.52 & 1.05 & 1.53 & 2.80 \\
\hline & $\mathrm{B} 2 \mathrm{t}$ & 0.01 & 0.37 & 2.78 & 2.94 & 6.32 & 12.24 \\
\hline & Cca & 0.00 & 0.52 & 2.24 & 1.46 & 2.14 & 3.62 \\
\hline \multirow{4}{*}{8} & A & 0.00 & 0.08 & 1.33 & 0.59 & 0.64 & 3.77 \\
\hline & Eet & 0.01 & 0.05 & 0.77 & 0.49 & 0.53 & 2.69 \\
\hline & $\mathrm{Bt}$ & 0.01 & 0.27 & 2.98 & 2.91 & 1.40 & 10.29 \\
\hline & $\mathrm{C}$ & 0.00 & 0.28 & 1.35 & 1.99 & 1.09 & 6.76 \\
\hline \multirow{3}{*}{9} & Ap & 0.01 & 0.14 & 1.87 & 1.49 & 0.97 & 6.96 \\
\hline & $\mathrm{Bt}$ & 0.01 & 0.36 & 2.78 & 3.99 & 1.35 & 11.40 \\
\hline & Cca & 0.03 & 0.50 & 1.48 & 1.84 & 1.13 & 6.84 \\
\hline
\end{tabular}


Table 4. Concentration of particular forms of phosphorus in examined soils ( $\left.\mathrm{mg} \mathrm{kg}^{-1}\right)$

\begin{tabular}{|c|c|c|c|c|c|c|}
\hline $\begin{array}{c}\text { Profile } \\
\text { No. }\end{array}$ & Horizon & SP & NAP & AP & OP & ТP \\
\hline \multirow{4}{*}{1} & $\mathrm{Ak}$ & 0.8 & 66.7 & 26.7 & 19.4 & 113.7 \\
\hline & $2 \mathrm{Ck} 1$ & 0.8 & 36.8 & 27.9 & 17.6 & 83.1 \\
\hline & $3 \mathrm{Ck} 2$ & 0.9 & 16.3 & 37.5 & 11.8 & 66.5 \\
\hline & $3 \mathrm{Ck} 3$ & 0.7 & 1.9 & 61.9 & 14.3 & 78.8 \\
\hline \multirow{3}{*}{2} & Auk & 8.9 & 41.4 & 38.6 & 90.0 & 179.0 \\
\hline & Cuk1 & 3.1 & 35.3 & 10.5 & 56.5 & 105.3 \\
\hline & $2 \mathrm{Cuk} 2$ & 2.1 & 52.6 & 11.8 & 26.7 & 93.2 \\
\hline \multirow{3}{*}{3} & Ak1 & 2.2 & 67.9 & 27.8 & 13.8 & 111.7 \\
\hline & Cuk2 & 1.1 & 28.0 & 27.6 & 18.3 & 75.0 \\
\hline & $\mathrm{Ck} 3$ & 0.7 & 1.8 & 50.2 & 5.4 & 58.1 \\
\hline \multirow{4}{*}{4} & $\mathrm{Ak}$ & 2.9 & 15.2 & 16.3 & 50.0 & 84.4 \\
\hline & 2Cuk1 & 2.6 & 20.3 & 11.4 & 32.9 & 67.2 \\
\hline & 2Cuk2 & 0.6 & 27.7 & 21.0 & 13.2 & 62.5 \\
\hline & $2 \mathrm{Ck} 3$ & 0.7 & 12.3 & 28.2 & 8.8 & 50.0 \\
\hline \multirow{4}{*}{5} & Ak1 & 1.1 & 64.0 & 31.7 & 28.6 & 125.4 \\
\hline & $\mathrm{Au} 2$ & 0.9 & 26.9 & 24.4 & 5.2 & 57.5 \\
\hline & Cuk1 & 0.6 & 16.5 & 19.1 & 11.0 & 47.1 \\
\hline & Cuk2 & 0.7 & 1.7 & 48.3 & 5.2 & 55.9 \\
\hline \multirow{4}{*}{6} & A & 4.5 & 75.9 & 21.7 & 150.2 & 252.3 \\
\hline & AEet & 3.1 & 101.6 & 56.8 & 64.5 & 226.0 \\
\hline & $\mathrm{Bt}$ & 3.1 & 250.9 & 100.5 & 73.1 & 427.6 \\
\hline & Cca & 2.5 & 7.2 & 232.9 & 53.8 & 296.4 \\
\hline \multirow{3}{*}{7} & $\mathrm{ApBt}$ & 3.1 & 133.1 & 101.6 & 92.5 & 330.3 \\
\hline & $\mathrm{B} 2 \mathrm{t}$ & 2.7 & 239.5 & 130.9 & 145.5 & 518.5 \\
\hline & $\mathrm{Cca}$ & 2.4 & 4.7 & 240.0 & 34.6 & 281.7 \\
\hline \multirow{4}{*}{8} & A & 10.7 & 122.6 & 36.3 & 196.1 & 365.7 \\
\hline & Eet & 7.2 & 182.7 & 41.1 & 92.6 & 323.6 \\
\hline & $\mathrm{Bt}$ & 5.0 & 302.0 & 165.9 & 49.5 & 522.3 \\
\hline & $\mathrm{C}$ & 5.1 & 124.5 & 122.9 & 81.5 & 333.9 \\
\hline \multirow{3}{*}{9} & Ap & 7.6 & 212.0 & 112.5 & 138.8 & 470.8 \\
\hline & $\mathrm{Bt}$ & 5.0 & 296.4 & 146.6 & 132.4 & 580.4 \\
\hline & $\mathrm{Cca}$ & 3.1 & 7.9 & 223.6 & 24.2 & 258.8 \\
\hline
\end{tabular}


Arsenic in soils occurs primarily in the form of inorganic compounds at various oxidation states. It mainly produces salts of oxygenated acids, arsenites and arsenates. Under reduced conditions, and in acidic environment, arsenic mainly occurs at a lower level of oxidation, and in mobile and toxic forms. In acidic environment, arsenates are not very mobile. However, at high soil $\mathrm{pH}$, arsenite mobility is limited, while arsenate mobility increases (Frankenberger, 2002). The relationship between the reaction and arsenic content did not prove statistically significant. No correlation was noted in the alkaline technosols and in the non-geomechanically-disturbed soils (arable and forest) that are characterised by acid reactions. However, phosphorus negatively correlated with $\mathrm{pH}$ in the group of technosols.

The conduction of arsenic speciation analysis made it possible to assess the mobility of this element in soil. On the basis of the percentage of each fraction in the total pool, it was also possible to specify the ecological risk. Of note, the more mobile forms posed a greater threat to the environment.

Arsenic and phosphorus forms in the group of technosols, when separated out via speciation analysis, exhibited great diversity. The forms sorbed by amorphous and crystalline iron oxides were characterised by the greatest share of arsenic in the general pool and averaged over 54\%, while the phosphorus content in an analogous fraction, and that fixed with calcium apatite (NAP+AP), averaged at $64 \%$. Arsenic and phosphorus forms separated in speciation analysis in the group of technosols exhibited great diversity. The above-mentioned soil components have a large influence on the immobilization of arsenic and phosphorus in the soil. The high affinity of arsenic and phosphorus forms to amorphous and crystalline iron oxides has also been confirmed by other researchers (Goldberg, 2002; Violante and Pigna, 2002; Wenzel et al., 2001).

In the total pool of arsenic extracted from studied soils, the number of mobile fractions (NSA $+\mathrm{SA}$ ), and at the same time bioaccessible fractions, amounted to approx. $11 \%$ and decreased with depth, while the soluble fraction of phosphorus SP amounted to an average of $1.7 \%$. In the second group of soils (non-transformed geomechanically), the share of arsenic in the general pool sorbed by amorphous and crystalline iron oxide was even higher than $70 \%$. For phosphorus in an analogous fraction, the equivalent figure was up to $50 \%$. Within the total pool of the forms of arsenic and phosphorus extracted from the non-geomechanically-transformed soils under examination, the number of mobile and, at the same time, bioaccessible elements extracted did not exceed $10 \%$. Furthermore, the share of the soluble forms of phosphorus in both forest soils and agricultural soils, decreased with depth, and correlated with a simultaneous growth in the share of the mobile forms of arsenic (NSA + SA). In agricultural soils, a greater share of mobile forms of arsenic (NSA + SA) was observed, along with and a smaller share of phosphorus forms, as compared to forest soils.

In the majority of the profiles examined, the share of the soluble forms of arsenic and phosphorus decreased with depth. The fact that the soluble As fraction represented a relatively small share of the total As content in most samples demonstrates the greater mobility of this fraction. The results of speciation analysis suggest that As was more mobile in more contaminated soils (such as Group 1 Technosol) than in less contaminated soils (such as Group 2). These results confirm that metals of anthropogenic origin are more mobile than those from soil matrix materials (Luo et al., 2008; Plak, 2007; Walczak et al., 2015).

Arsenic proved to display greater mobility in more polluted soils. In general, high values were noted for the extracted crystalline and amorphous elements, while the proportion of these forms was lower in more contaminated soils. In non-anthropogenic soils, a higher share of AA and CA was found in the total arsenic pool than in the case of technosols, which is probably due to specific substrate properties. Crystalline and amorphous forms are important because, as a result of changes in the habitat conditions, e.g. reactions, they can cause arsenic to pass into bioavailable forms. The presence of residual arsenic, strongly bound and poorly available, increased with soil depth, as confirmed by Wenzel et al. (2001).

The binding of arsenic and phosphorus by many soil components brings about its accumulation in the surface profiles. This particularly concerns locations subjected to strong anthropopressure (e.g. cities), which accumulate various pollutions, as in the case of arsenic, or provide degradable organic substance or practice agro-fertilisation, as in the case of phosphorus (Luo et al., 2008; Nriagu, 1994; Wei et al., 2010; Wu et al., 2010).

Urban soils are likely to exhibit increased concentrations of arsenic, due to the varied application of the element in the broadly understood chemical industry, including in paints, dyes, ceramics, electronics, fertilizers, plant protection products. Arsenic may also be sourced from fossil fuel combustion and industrial waste (Nriagu, 1994). A comparison of the arsenic content in urban soils of different functions and different usage forms has revealed that residents of Lublin are exposed mainly through contact with soil, especially in industrialised areas, and to a lesser extent, by the consumption of food grown in rural areas of the Lublin agglomeration, or by staying in a residential area or in the forest.

Statistical analyses were performed to compare the results obtained for each profile of anthropogenic origin, and for close-to-natural profiles. The soils of the two groups showed a clear segregation in the PCA diagram (Fig. 1). Furthermore, two major factors explained over $63 \%$ of the entire variation between the cases (measurements). However, the contribution of each variable differed. Factor 


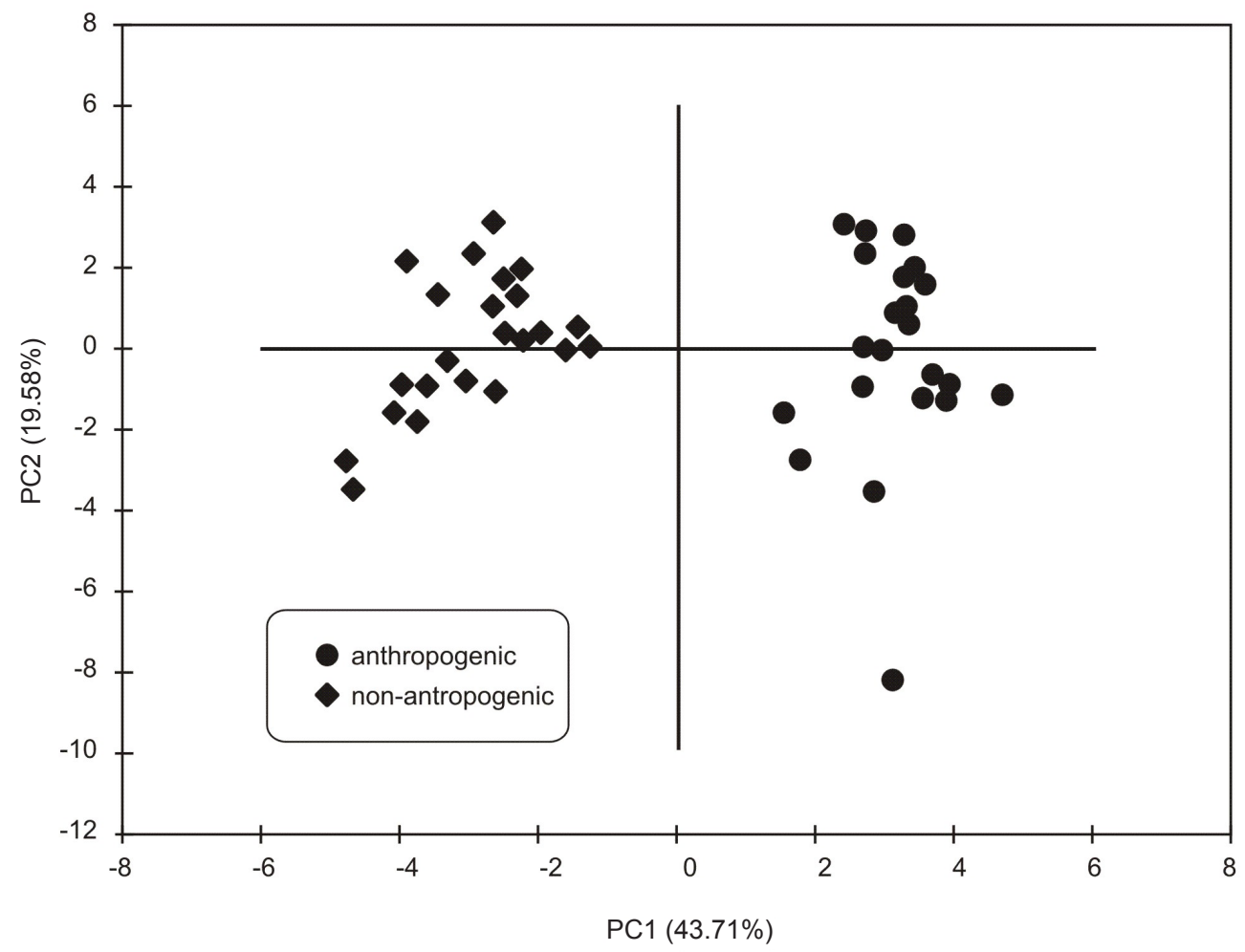

Fig. 1. PCA diagram - projection of cases on components plane, made on the basis of all analysed habitat parameters.

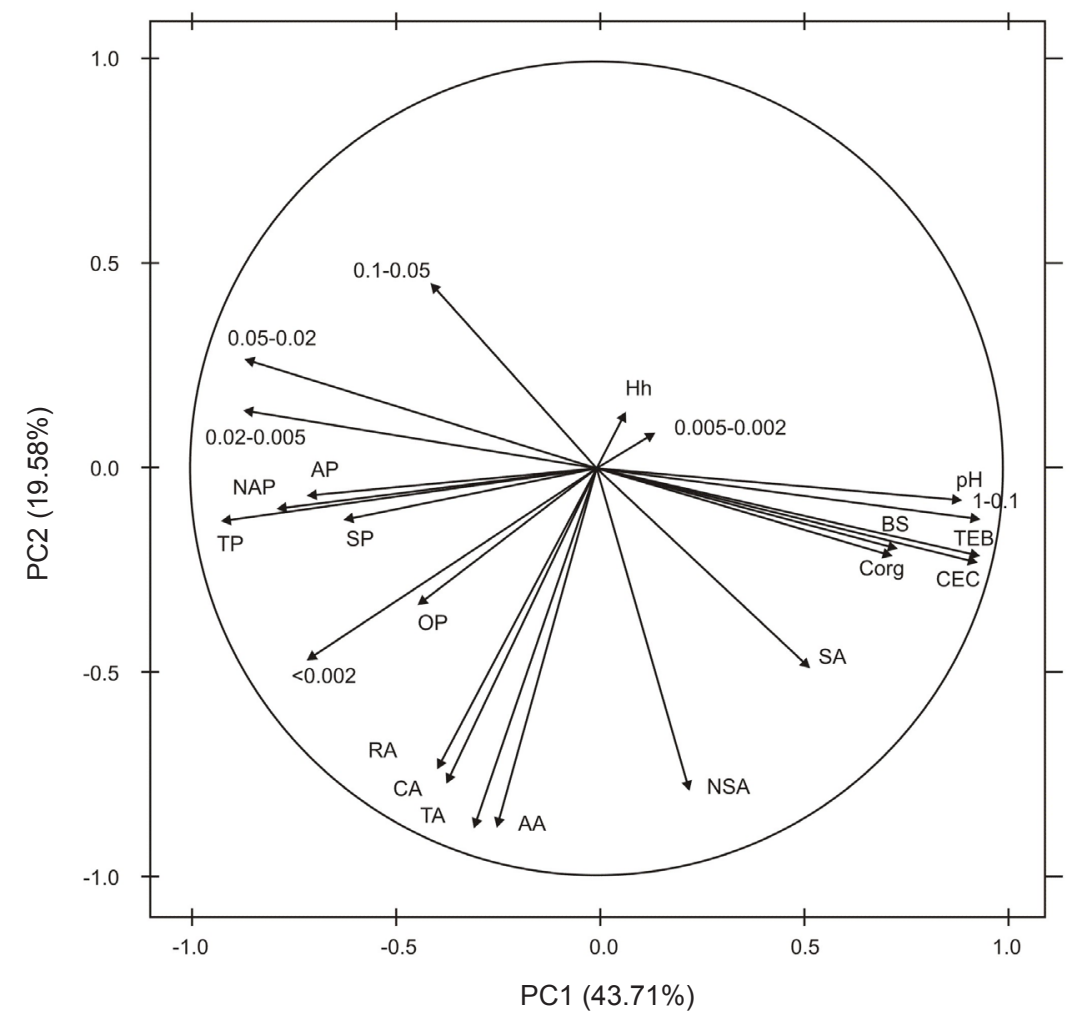

Fig. 2. PCA diagram - projection of variables on components plane, made on the basis of all analysed habitat parameters. 
Table 5. Correlation coefficients between determined soils parameters (Technosols)

\begin{tabular}{|c|c|c|c|c|c|c|c|c|c|c|c|}
\hline & NSA & SA & AA & $\mathrm{CA}$ & RA & TA & SP & NAP & AP & OP & PT \\
\hline $1-0.1$ & 0.13 & -0.05 & 0.07 & 0.05 & 0.30 & 0.11 & 0.24 & -0.38 & -0.04 & 0.15 & -0.17 \\
\hline $0.1-0.05$ & -0.02 & -0.28 & -0.33 & -0.26 & -0.43 & -0.30 & -0.22 & 0.43 & 0.04 & -0.20 & 0.17 \\
\hline $\begin{array}{l}0.05- \\
0.02\end{array}$ & -0.21 & -0.29 & -0.35 & -0.42 & -0.54 & -0.44 & -0.38 & 0.14 & 0.18 & -0.30 & -0.04 \\
\hline $\begin{array}{l}0.02- \\
0.005\end{array}$ & 0.06 & 0.23 & 0.14 & 0.03 & -0.12 & 0.02 & -0.08 & 0.35 & 0.10 & 0.01 & 0.28 \\
\hline $\begin{array}{l}0.005- \\
0.002\end{array}$ & 0.17 & 0.17 & 0.14 & 0.02 & -0.05 & 0.00 & 0.04 & 0.52 & -0.30 & 0.11 & 0.30 \\
\hline$<0.002$ & -0.23 & 0.50 & 0.33 & 0.53 & 0.24 & 0.44 & -0.03 & 0.20 & -0.13 & 0.05 & 0.11 \\
\hline C org. & 0.43 & 0.34 & 0.38 & 0.09 & 0.27 & 0.20 & 0.28 & 0.43 & -0.21 & 0.33 & 0.43 \\
\hline $\mathrm{pH}$ & -0.24 & -0.32 & -0.32 & -0.30 & -0.19 & -0.36 & -0.22 & -0.23 & -0.18 & -0.39 & -0.49 \\
\hline $\mathrm{CaCO}_{3}$ & 0.26 & 0.55 & 0.56 & 0.67 & 0.56 & 0.70 & 0.46 & 0.47 & -0.28 & 0.50 & 0.55 \\
\hline $\mathrm{Hh}$ & 0.16 & 0.17 & 0.14 & -0.14 & 0.01 & -0.05 & 0.00 & 0.26 & -0.35 & 0.14 & 0.12 \\
\hline TEB & 0.20 & 0.53 & 0.50 & 0.62 & 0.55 & 0.63 & 0.39 & 0.21 & -0.35 & 0.45 & 0.30 \\
\hline CEC & 0.20 & 0.53 & 0.50 & 0.62 & 0.55 & 0.62 & 0.39 & 0.22 & -0.36 & 0.45 & 0.31 \\
\hline BS & -0.11 & 0.05 & 0.08 & 0.40 & 0.23 & 0.31 & 0.15 & -0.24 & 0.20 & 0.02 & -0.06 \\
\hline NSA & & 0.45 & 0.74 & 0.39 & 0.69 & 0.53 & 0.86 & 0.34 & 0.06 & 0.78 & 0.80 \\
\hline SA & & & 0.87 & 0.68 & 0.82 & 0.81 & 0.53 & 0.25 & -0.27 & 0.57 & 0.45 \\
\hline $\mathrm{AA}$ & & & & 0.72 & 0.93 & 0.86 & 0.82 & 0.22 & -0.15 & 0.82 & 0.65 \\
\hline CA & & & & & 0.76 & 0.88 & 0.64 & 0.15 & -0.29 & 0.66 & 0.43 \\
\hline RA & & & & & & 0.94 & 0.87 & 0.14 & -0.18 & 0.84 & 0.60 \\
\hline TA & & & & & & & 0.80 & 0.21 & -0.27 & 0.83 & 0.60 \\
\hline SP & & & & & & & & 0.18 & -0.08 & 0.92 & 0.73 \\
\hline NAP & & & & & & & & & -0.26 & 0.18 & 0.70 \\
\hline AP & & & & & & & & & & -0.25 & 0.08 \\
\hline $\mathrm{OP}$ & & & & & & & & & & & 0.70 \\
\hline PT & & & & & & & & & & & \\
\hline
\end{tabular}

Marked values are significant at $\mathrm{p}<0.05$.

$1 \mathrm{PC} 1$, explaining almost $44 \%$ of the variation, was characterised by the highest contribution of fraction $1-0.1 \mathrm{~mm}$, CEC, TP and exchangeable cations (Fig. 2). The highest contribution to factor 2 PC2 (almost $20 \%$ of the variance) was made by the following parameters: SA, AA and TA (total arsenic content). Scores PC1 and PC2 were also notably different; in the first case, these averaged at -0.1487 and -0.0664 (respectively, for the PC1 and PC2) and the standard deviations were $\mathrm{SD}=2.6$ and 1.3 ; while in the second, the corresponding figures were 0.1423 and 0.0636 , respectively, with $\mathrm{SD}=1.6$ for both components.

A clear distinction between both groups was also demonstrated by way of assessing the correlation between all the parameters examined, which was performed separately for technosols (Table 5) and semi-natural soils (Table 6). In the first case, important correlations were 
Table 6. Correlation coefficients between determined soils parameters (non-anthropogenic soils)

\begin{tabular}{|c|c|c|c|c|c|c|c|c|c|c|c|}
\hline & NSA & SA & AA & $\mathrm{CA}$ & RA & TA & SP & NAP & $\mathrm{AP}$ & $\mathrm{OP}$ & PT \\
\hline $1-0.1$ & 0.96 & 0.20 & -0.96 & 0.98 & -0.73 & 1.00 & 0.67 & 0.98 & -0.83 & -1.00 & -0.12 \\
\hline $0.1-0.05$ & 0.35 & -0.65 & -0.36 & 0.43 & -0.99 & 0.68 & 1.00 & 0.76 & -0.95 & -0.62 & -0.86 \\
\hline $\begin{array}{l}0.05- \\
0.02\end{array}$ & 0.73 & 0.95 & -0.73 & 0.67 & 0.22 & 0.42 & -0.31 & 0.32 & 0.08 & -0.49 & 0.80 \\
\hline $\begin{array}{l}0.02- \\
0.005\end{array}$ & -0.96 & -0.20 & 0.96 & -0.98 & 0.73 & -1.00 & -0.67 & -0.98 & 0.83 & 1.00 & 0.12 \\
\hline $\begin{array}{l}0.005- \\
0.002\end{array}$ & -0.22 & 0.75 & 0.23 & -0.30 & 0.96 & -0.58 & -0.98 & -0.66 & 0.90 & 0.51 & 0.92 \\
\hline$<0.002$ & -0.22 & 0.75 & 0.23 & -0.30 & 0.96 & -0.58 & -0.98 & -0.66 & 0.90 & 0.51 & 0.92 \\
\hline C org. & 0.88 & 0.01 & -0.89 & 0.92 & -0.85 & 1.00 & 0.80 & 1.00 & -0.92 & -0.98 & -0.31 \\
\hline $\mathrm{pH}$ & 0.13 & 0.93 & -0.12 & 0.04 & 0.80 & -0.26 & -0.84 & -0.37 & 0.70 & 0.18 & 1.00 \\
\hline $\mathrm{CaCO}_{3}$ & 0.14 & 0.94 & -0.13 & 0.06 & 0.79 & -0.25 & -0.84 & -0.35 & 0.69 & 0.17 & 1.00 \\
\hline $\mathrm{Hh}$ & -0.16 & 0.79 & 0.17 & -0.24 & 0.94 & -0.52 & -0.96 & -0.61 & 0.87 & 0.45 & 0.94 \\
\hline TEB & 0.68 & 0.97 & -0.67 & 0.61 & 0.30 & 0.34 & -0.38 & 0.24 & 0.16 & -0.42 & 0.84 \\
\hline CEC & 0.67 & 0.97 & -0.66 & 0.60 & 0.31 & 0.34 & -0.39 & 0.23 & 0.17 & -0.41 & 0.85 \\
\hline BS & 0.70 & -0.29 & -0.71 & 0.76 & -0.97 & 0.92 & 0.94 & 0.96 & -0.99 & -0.88 & -0.58 \\
\hline NSA & & 0.48 & -1.00 & 1.00 & -0.50 & 0.92 & 0.42 & 0.88 & -0.62 & -0.95 & 0.18 \\
\hline SA & & & -0.47 & 0.40 & 0.52 & 0.11 & -0.59 & 0.00 & 0.39 & -0.19 & 0.95 \\
\hline AA & & & & -1.00 & 0.51 & -0.93 & -0.43 & -0.88 & 0.63 & 0.96 & -0.16 \\
\hline $\mathrm{CA}$ & & & & & -0.57 & 0.95 & 0.50 & 0.91 & -0.69 & -0.98 & 0.09 \\
\hline RA & & & & & & -0.79 & -1.00 & -0.85 & 0.99 & 0.74 & 0.77 \\
\hline $\mathrm{TA}$ & & & & & & & 0.74 & 0.99 & -0.87 & -1.00 & -0.21 \\
\hline SP & & & & & & & & 0.81 & -0.97 & -0.68 & -0.82 \\
\hline NAP & & & & & & & & & -0.92 & -0.98 & -0.32 \\
\hline AP & & & & & & & & & & 0.83 & 0.66 \\
\hline OP & & & & & & & & & & & 0.13 \\
\hline PT & & & & & & & & & & & \\
\hline
\end{tabular}

Explanations as in Table 5 .

shown, in particular, between individual forms of arsenic and phosphorus. In the case of non-anthropogenic soils, there were no statistically significant relationships. This phenomenon is probably conditioned by anthropogenic pressure or lack of it, which strengthens interactions between particular environmental factors.

\section{CONCLUSIONS}

1. The amount of arsenic in the technosols of Lublin was estimated as being at harmless levels, from the point of view of environmental and health risk. Indeed, the concentration of this element was elevated in only some surface horizons. The greatest amount of phosphorus was found in 
the non-anthropogenic soils, this being a result of the natural processes of accumulation of this element connected with the biological activity of soils. However, anthropopression is a secondary factor.

2. On the basis of the sequential extraction procedure, it may be concluded that the environmental risk connected with arsenic levels in Lublin's soils should be evaluated as low. Most of the element is strongly bound while the most mobile forms showed low concentrations. Slightly higher concentrations were noted in technosols.

3 . The conduction of speciation analysis for two elements of similar electron configurations makes it possible to effectively analyse the behaviour of these elements, as dependent upon on soil processes. Statistical analyses have shown that anthropopression is likely to bring about greater interdependence between the behaviour of the forms of the elements analysed and basic soil properties. The dissimilarity of the two groups of soils, as demonstrated with principal component analysis, shows the significant impact of the urban agglomeration on soil cover properties.

4. Arsenic and phosphorus mobility was reduced in the second group of soils, and specifically in soil horizons where smaller soil fractions have been accumulated.

5. Studies on the competition of phosphate and arsenic ions sorbed on different soil components may help in determining the appropriate strategy for the reclamation of different soils contaminated with arsenic.

Conflict of interest: The Authors do not declare conflict of interest.

\section{REFERENCES}

Ascar L., Ahumada I., and Richter P., 2008. Influence of redox potential (Eh) on the availability of arsenic species in soils and soil amended with biosolid. Chemosphere, 72, 15481552, doi:10.1016/j.chemosphere.2008.04.056

Bolan N., Mahimairaja S., Kunhikrishnan A., and Choppala G., 2013. Phosphorus-arsenic interactions in variablecharge soils in relation to arsenic mobility and bioavailability. Sci. Total Environ., 463-464, 1154-1162, doi:10.1016/j.scitotenv.2013.04.016

Chang S.C. and Jackson M.L., 1957. Fractionation of soil phosphorus. Soil Sci., 84(2), 133-144.

Chen M., Chen J., and Sun F., 2008. Agricultural phosphorus flow and its environmental impacts in China. Sci. Total Environ., 405, 140-152, doi: 10.1016/j.scitotenv.2008. 06.031

Frankenberger W.T., 2002. Environmental Chemistry of Arsenic. Marcel Dekker, New York, USA.

Garcia-Sanchez A., Alvarez-Ayuso E., and Rodriguez-Martin F., 2002. Sorption of $A s(V)$ by some oxyhydroxides and clay minerals : Applicatiuon to its immobilisation in two polluted mining soils. Clay Minerals, 37, 187-194.

Goldberg S., 2002. Competitive Adsorption of Arsenate and Arsenite on Oxides and Clay Minerals. Soil Sci. Soc. Am. J., 66, 413-421, doi:10.2136/sssaj2002.4130
Hartley W., Dickinson N.M., Riby P., Leese E., Morton J., and Lepp N.W., 2010. Arsenic mobility and speciation in a contaminated urban soil are affected by different methods of green waste compost application. Environ. Pollut., 158, 3560-3570, doi: 10.1016/j.envpol.2010.08.15

Hieltjes A.H.M. and Lijklema L., 1980. Fractionation of inorganic phosphates in calcareous sediments. J. Environ. Qual., 9,405-407, doi:10.2134/jeq1980.00472425000900030015x

ISO 10390:1994. Soil quality - Determination of $\mathrm{pH}$, Chemical characteristics of soils.

ISO 11466:1995. Soil quality - Extraction of trace elements soluble in 'aqua regia'.

IUSS Working Group, 2014. World Reference Base for Soil Resources 2014. International soil classification system for naming soils and creating for soil maps. World Soil Resources Reports No. 106, FAO, Rome.

Jiang Y., Zeng X., Fan X., Chao S., Zhu M., and Cao H., 2015. Levels of arsenic pollution in daily foodstuffs and soils and its associated human health risk in a town in Jiangsu Province, China. Ecotoxicol. Environ. Saf., 122, 198-204, doi:10.1016/j.ecoenv.2015.07.018

Kociuba D., 2011. Lublin spatial and functional development from the Middle Ages to the Present (in Polish). Wyd. Marszałek, Toruń, Poland.

Krysiak A. and Karczewska A., 2007. Arsenic extractability in soils in the areas of former arsenic mining and smelting, SW Poland. Scie. Tot. Environ., 379, 190-200, doi: 10.1016/j.scitotenv.2006.09.031

Kuo S., 1996. Phosphorus. In: Methods of soil analysis Part 3. Chemical methods (Eds D.L. Sparks, A.L. Page, P.A. Helmke, R.H. Loeppert, P.N. Soltanpour, M.A. Tabatabai, C.T. Johnston, M.E. Sumner). Soil Science Society of America Book. Soil Sci. Soc. Am. Madison, USA, 869-920.

Lauer F., Pätzold S., Gerlach R., Protze J., Willbold S., and Amelung W., 2013. Phosphorus status in archaeological arable topsoil relicts. Is it possible to reconstruct conditions for prehistoric agriculture in Germany?, Geoderma, 207208, 11-120, doi: 10.1016/j.geoderma.2013.05.005

Lu Y., Yin W., Huang L., Zhang G., and Zhao Y., 2011. Assessment of bioaccessibility and exposure risk of arsenic and lead in urban soils of Guangzhou City, China. Environ. Geochem. Health., 33, 93-102, doi:10.1007/s10653-0109324-8

Luo W., Lu Y., Wang G., Shi Y., Wang T., and Giesy J.P., 2008. Distribution and availability of arsenic in soils from the industrialized urban area of Beijing, China. Chemosphere, 72(5), 797-802, doi: 10.1016/j.chemosphere.2008.03.003

Nelson D.W. and Sommers L.E., 1996. Total Carbon, Organic Carbon, and Organic Matter In: Sparks D. L., Page A. L., Helmke P. A., Loeppert R. H., Soltanpour P. N., Tabatabai M.A., Johnston C. T, Sumner M. E. (Eds.). Methods of soil analysis. Part 3. Chemical methods, Soil Science Society of America Book Series: 5. Soil Sci. Soc. Am. Madison, USA.

Nielsen N.H. and Kristiansen S.M., 2014. Identifying ancient manuring: traditional phosphate $v s$. multi-element analysis of archaeological soil. J. Arch. Scie., 42, 390-398, doi: 10.1016/j.jas.2013.11.013

Nriagu J.O., 1994. Arsenic in the environment. Part I: Cycling and Characterization. Wiley and Sons, New York, USA. 
Ostrowska A., Gawliński S., and Szczubiałka Z., 1991. Methods of analysis and evaluation of soil properties and plant - Catalogue (in Polish). Institute of Environmental Protection, Warsaw, Poland.

Pardo P., Rauret G., and Lopez-Sanchez J.F., 2003. Analytical approaches to the determination of phosphorus partitioning patterns in sediments. J. Environ. Monit., 5, 312-318, doi: 10.1039/B210354

Plak A., 2007. Factors formative content and forms of arsenic in soils of Lublin agglomeration (in Polish). Acta Agrophysica, 149, 1-149.

Rodrigues S.F.S. and Lima da Costa M., 2016. Phosphorus in archeological ceramics as evidence of the use of pots for cooking food. App. Clay. Sci., 123, 224-231, doi:10.1016/j. clay.2015.10.038

Ryżak M., Bartmiński P., and Bieganowski A., 2009. Methods of assessment of grain-size distribution of mineral soils (in Polish). Acta Agrophysica, 175, 1-97.

Torbert H.A., Daniel T.C., Lemunyon J.L., and Jones R.M., 2002. Relationship of soil test phosphorus and sampling depth to runoff phosphorus in calcareous and noncalcareous soils. J. Environ. Qual., 31(4), 1380-1387.

Violante A. and Pigna M., 2002. Competitive sorption of arsenate and phosphate of different clay minerals and soils. Soil Sci. Soc. Am. J., 66, 1788-1796.

Walczak B., Kostecki J., Wasylewicz R., Lassota T., Greinert
A., and Drab M., 2015. The content of lead in soils of allotment gardens in Zielona Góra, Poland. Pol. J. Soil Sci., 48, 41-46, doi:10.17951/pjss/2015.48.1.41

Wei B. and Yang L., 2010. A review of heavy metal contaminations in urban soils, urban road dusts and agricultural soils from China. Microchem. J., 94, 99-107, doi:10.1016/j. microc.2009.09.014

Wenzel W., Kirchbaumer N., Prohaska T., Stingeder G., Lombi E., and Adriano D., 2001. Arsenic fractionation in soils using an improved sequential extraction procedure. Anal. Chim. Acta, 436, 309-323.

Wolfe-Simon F., Blum J.S., Kulp T.R., Gordon G.W., Hoeft S.E., Pett-Ridge J.,Stolz J.F., Webb S.M., Weber P.K., Davies P.C.W., Anbar A.D., and Oremland R.S., 2011. A Bacterium That Can Grow by Using Arsenic Instead of Phosphorus. Science, 332(6034), 1163-1166, doi: 10.1126/ science. 1197258

Wong C.S.C., Li X., and Thornton I., 2006. Urban environmental geochemistry of trace metals. Environ. Pollut., 14, 1-16, doi: 10.1016/j.envpol.2005.09.004

Wu S., Xia X., Lin C., Chen X., and Zhou Ch., 2010. Levels of arsenic and heavy metals in rural soils of Beijing and their changes over the last two decades (1985-2008). J. Hazard. Mater., 179(1-3), 860-868, doi:10.1016/j.jhazmat.2010.03.084

Zhao X. and Xia X., 2012. Total nitrogen and total phosphorous in urban soils used for different purposes in Beijing, China. Proc. Environ. Sci., 13, 95-104, doi:10.1016/j.proenv.2012. 1.009 